\title{
Rediscovery of Hyophryne histrio (Anura, Microhylidae) in Atlantic Forest remnants of Bahia, northeastern Brazil
}

\author{
Marianna Dixo \\ Departamento de Ecologia. Instituto de Biociências, Universidade de São Paulo. R. do Matão 321, 05508-900, São \\ Paulo, SP, Brazil. Email: maridixo@ib.usp.br.
}

Keywords: Anura, Microhylidae, Hyophryne histrio, rediscovery, Atlantic Forest, Bahia, northeastern Brazil.

Hyophryne histrio was described by Carvalho (1954) based on a single immature specimen deposited in the herpetological collection of Museu Nacional of Rio de Janeiro (MNRJ). João Geraldo Santos collected the type species of this monotipic genus in March 1944 at Fazenda Repartimento, municipality of Ilhéus, state of Bahia, northeastern Brazil. Since then, there was no new record of this frog.

Recently, the RestaUna Project - Forest Remnants of Una, South Bahia (Núcleo de Estudos da Mata Atlântica - Universidade Santa Cruz) was designed to investigate the comparative response of several biological groups facing forest fragmentation. Series of pitfall traps were placed in different habitats to undertake the herpetofauna survey: primary forest of Una Reserve (15 $\left.10^{\circ} \mathrm{S}, 39^{\circ} 31^{\prime} \mathrm{W}\right)$ and surroundings, forest fragments, secondary forest and cacao groves. These habitats were sampled in three geographical blocks (Figure 1).

Between October 1999 and February 2000 a total of 42 specimens of Hyophryne histrio were collected on all habitats studied: primary

Received 22 April 2004.

Accepted 8 June 2004.

Distributed 30 September 2004.

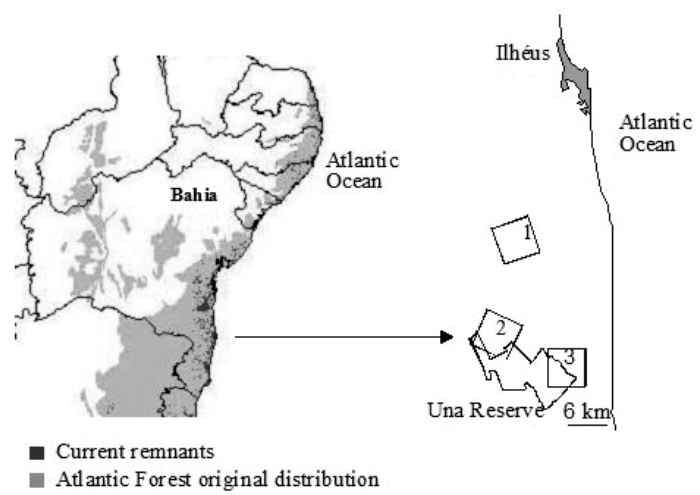

Figure 1 - Map of northeastern Brazil, showing the original distribution and current remnants of Atlantic Forest and location of Una Biological Reserve and the three studied blocks.

forest interior $(\mathrm{N}=4)$, primary forest edge $(\mathrm{N}=1)$, forest fragment interior $(\mathrm{N}=7)$, forest fragment edge $(\mathrm{N}=7)$, secondary forest $(\mathrm{N}=6)$, and cacao grove $(\mathrm{N}=17)$. Although slightly more frequent in the cacao groves, the abundance of $H$. histrio does not vary significantly among different habitats [Kruskal-Wallis test: $\mathrm{H}(5, \mathrm{~N}=36)=7.35$, $\mathrm{p}=0.20]$. All individuals were collected by pitfall traps, and no specimen was found on the forest leaf litter or temporary ponds. Some 

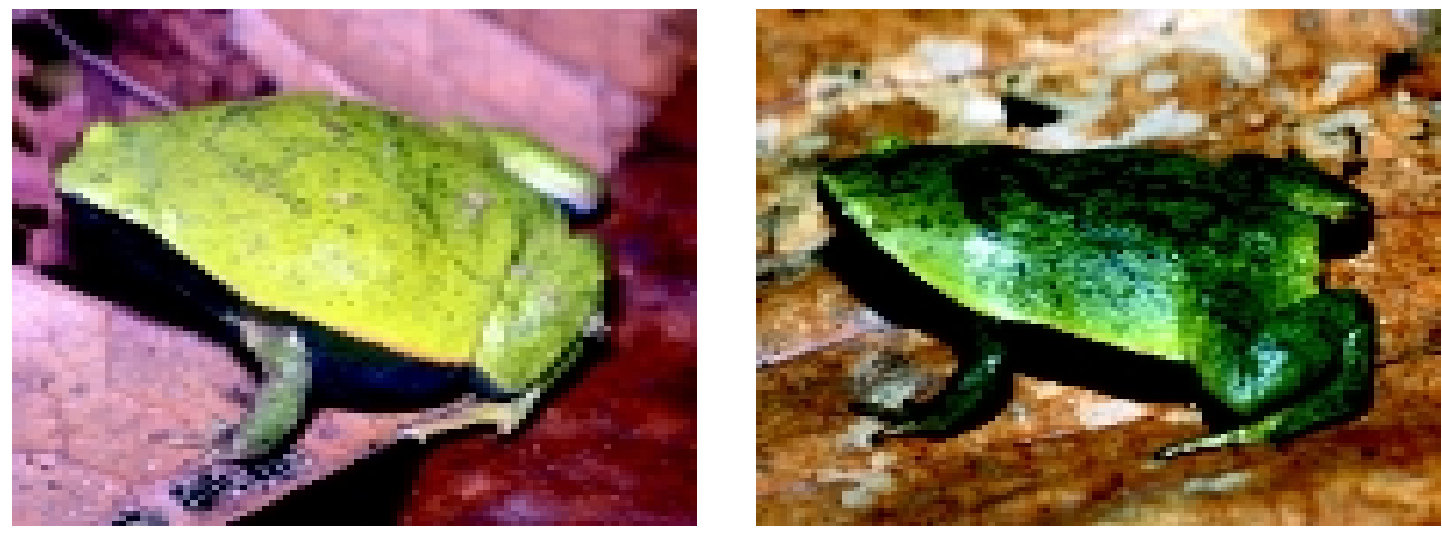

Figure 2 - Hyophryne histrio from Una, Bahia, Brazil. (A) yellowish and (B) greenish specimens.

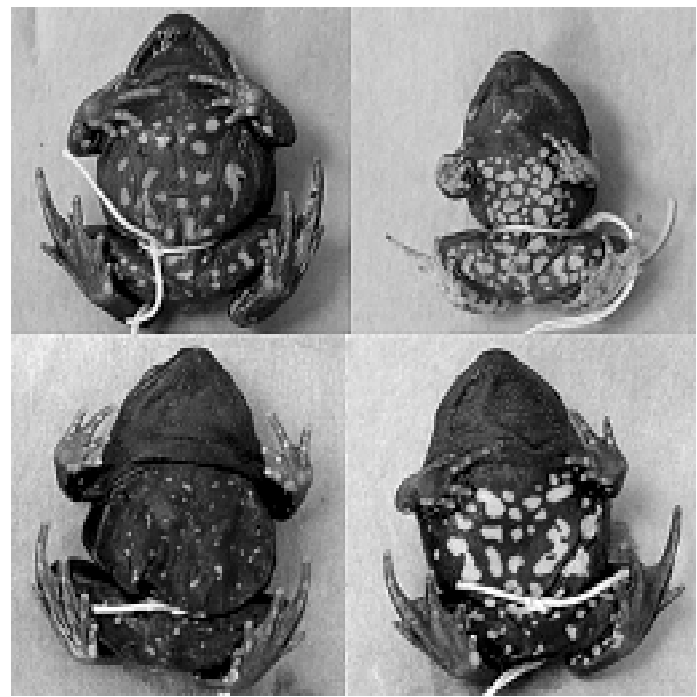

Figure 3 - Ventral view of four specimens of Hyophryne histrio from Una, Bahia (MZUSP 132328, 132342-3, 132357).

specimens were also sampled by pitfall traps in a preliminary survey in the same area in January 1999. The collected animals display great color variation on upper surfaces of head, body and limbs (yellowish, orange, green, beige, or dark brown), and an irregular, roughly arrow-shaped dark mark on dorsum (Figure 2). Lower surface is black with several light spots, varying in number and shape (Figure 3). The snout-vent length of a series of 34 specimens deposited in Museu de Zoologia da Universidade de São Paulo (MZUSP) varied from 24 to $41 \mathrm{~mm}$. The collected specimens were deposited in the herpetological collection of MNRJ (MNRJ 28564-28573) and in the herpetological collection of MZUSP (MZUSP 132326132359).

Two other surveys of Atlantic Forest and cacao plantation herpetofauna were carried out, also by means of pitfall traps, at Jussari in March 2001 (RPPN Serra do Teimoso, $15^{\circ} 09^{\prime} \mathrm{S}$, $39^{\circ} 31^{\prime} \mathrm{W}$ ) and Uruçuca in April and May 2002 (14 $\left.33^{\circ} \mathrm{S}, 39^{\circ} 18^{\prime} \mathrm{W}\right)$, distant $46 \mathrm{~km}$ and $69 \mathrm{~km}$ from Una, respectively. Despite the high sampling effort, Hyophryne histrio was not captured at these localities, what leads me to consider that this species either is not present there or, if present, is less abundant than in Una.

The Atlantic forest of eastern Bahia is among the threatened hotspot of the world (Mittermeier and Mittermeier 1997). The original forest has been suffering the effects of fragmentation and other anthropic pressures, which were intensified during the last decades by the decadence of cacao plantations (Alger and Caldas 1996). Most of the forest 
surrounding the reserve has been selectively cut to accommodate cacao plantation and other crops or cleared for cattle ranching. A few fragments of primary forest remain. In cacao groves, large emergent trees are preserved to shade the understory cacao plants. Notwithstanding its higher degree of disturbance compared to primary forest, cacao groves provide shelter and humidity for forest animals, apparently protecting them from extirpation in open area (Araujo et al. 1988, Argôlo 2004).

The information provided herein discloses the scarcity of knowledge on Brazilian herpetofauna, particularly from Atlantic Forest fragments, a habitat increasingly endangered. Hitherto, Hyophryne histrio was only known from its original description, based on a single specimen collected in Ilhéus nearly 60 years ago. This species seems much more common than expected upon the data gathered from Una (Dixo 2001). The absence of $H$. histrio in simi- lar habitats, forested fragments and cacao plantation near Una and Ilhéus may denote the endangered condition of this species, which is apparently endemic to a restricted, fragmented, and threatened region. More pitfall traps surveys need to be done to corroborate or reject this hypothesis.

\section{Acknowledgments}

Species were all verified by Eugenio Izeckson and J. P. Pombal Jr.. I thank Miguel Trefaut Rodrigues, Fabio Gaiger and Antônio Jorge Argôlo for review and comments on the manuscript. Miguel Trefaut Rodrigues, Dante Pavan, Vanessa Verdade, Kenji Kato and José Mario Beloti Ghellere helped in field work. I thank Fundação de Amparo à Pesquisa do Estado de São Paulo (FAPESP) for support. RestaUna project was funded by PROBIO (MMA), CNPq, GEF and BIRD.

\section{References}

Alger, K. and M. Caldas. 1996. Cacau na Bahia: decadência e ameaça à Mata Atlântica. Ciência Hoje 20: 28 35 .

Araújo, M., K. Alger, R. Rocha and C. A. B Mesquita. 1998. A Mata Atlântica do Sul da Bahia - situação atual, ações e perspectivas. Série Cadernos da Biosfera, Reserva da Biosfera da Mata Atlântica, MAB, UNESCO, Caderno 8. São Paulo. Instituto Florestal. $35 \mathrm{pp}$.

Argôlo A. J. S. 2004. As serpentes dos cacauais do sudeste da Bahia. Ilhéus. Editus. 260 pp.
Carvalho, A. L. 1954. A preliminary synopsis of the genera of American Microhylid frogs. Occasional Papers of the Museum of Zoology, University of Michigan 555: 1-19.

Dixo, M. 2001. Efeito da fragmentação da floresta sobre a comunidade de sapos e lagartos de serapilheira no sul da Bahia. Unpublihed M.Sc. Dissertation. Universidade de São Paulo, Brazil.

Mittermeier, R. A. and C. G. Mittermeier. 1997. Megadiversity. Earth's biologically wealthiest nations. CEMEX. Quebec. Quebecor Printing. 510 pp. 